\title{
HUBUNGAN STRATEGI MEKANISME KOPING DENGAN TINGKAT KECEMASAN MENGHADAPI PEMBELAJARAN KLINIK PADA MAHASISWA SEMESTER IV PROGRAM STUDI ILMU KEPERAWATAN STIKES DIAN HUSADA MOJOKERTO
}

\author{
Yufi Aris Lestari ${ }^{1 *}$, Hartin Suidah ${ }^{1}$, Nur Chasanah ${ }^{1}$, Elvatir Nusri Nur ${ }^{1}$ \\ ${ }^{1}$ STIKES Dian Husada Mojokerto \\ *Correspondence: \\ Yufi Aris Lestari \\ Email: yufiarislestari@gmail.com
}

\begin{abstract}
Background: Coping is the process of facing the difficulties of life in an attempt to overcome or live. Coping mechanism is a mechanism that consciously or not, to use a person in coping with stress or anxiety (Weller, 2005). In fact, there are some students who cannot cope with his anxiety so well that using negative coping mechanisms strategy.

Purpose: This study aimed to determine the correlation of strategy coping mechanisms dealing with anxiety level students learning in clinical studies IV semester of nursing STIKES Dian Husada Mojokerto.

Method: In this study, the research design used is analytic correlation with cross-sectional approach. This study is the student population by 67 students. Sampling technique using cluster random sampling with a sample of 58 respondents. The research data was taken with HRSA questionnaire sheet and questionnaire. Analysis of data using statistical test Spearman Rho.

Results: The results showed the majority of respondents $(63.8 \%)$ had a maladaptive coping mechanism-strategies as many as 37 respondents and the majority of respondents $(60.3 \%)$ had mild anxiety level as many as 35 respondents. Results of this study no relationship strategy coping mechanisms to face the anxiety level of clinical learning in students of fourth semester School of Nursing STIKES Dian Husada Mojokerto. This study used Spearman Rho test $\mathrm{p}$ value obtained was $0.013<\alpha=0.05$.

Conclusion: From the results, there is a relationship strategy coping mechanisms to face the anxiety level of learning clinic in the fourth semester student of School of Nursing STIKES Dian Husada Mojokerto. This study provides implications for the educators that research results be used as a reference in the plan to reduce student anxiety in the face of clinical learning.

Key words: Strategy coping mechanisms, level anxiety, facing student learning clinic
\end{abstract}

\section{PENDAHULUAN}

Kecemasan dialami oleh siapapun, dimanapun, dan kapanpun, tidak terkecuali mahasiswa. Ketika mengalami kecemasan, individu menggunakan berbagai mekanisme koping atau cara penyelesaian masalah, dan jika tidak dapat mengatasi kecemasan secara sehat, dapat menyebabkan perilaku yang maladaptif sehingga mengalami koping individu yang tidak efektif (Keliat, 2011). Pada kenyataannya ada beberapa mahasiswa yang tidak dapat mengatasi kecemasannya dengan baik sehingga menggunakan strategi mekanisme koping maladaptif. 
Berdasarkan hasil wawancara dilakukan oleh peneliti pada tanggal 8 November 2014 terhadap 6 mahasiswa tingkat II Program Studi Ilmu Keperawatan STIKES Dian Husada Mojokerto bahwa mahasiswa menyatakan mengalami kecemasan sebelum melaksanakan pembelajaran klinik.

Reilly dan Obermann dalam Nursalam (2008) menyatakan bahwa masalah nyata yang dihadapi di lahan praktek membuat mahasiswa harus berespon terhadap tantangan dengan mencari pengetahuan dan ketrampilan sebagai alternatif untuk menyelesaikannya. Menghadapi praktik klinik ini tidak jarang membuat mahasiswa menjadi cemas sebab pada umumnya ini menjadi pengalaman yang baru untuk mereka.Pembelajaran klinik menjadi kegiatan yang sulit bagi mahasiswa apabila mereka tidak bisa menyesuaikan kondisi terhadap masalah tersebut. Sedangkan jika masalah tersebut dapat terselesaikan dengan baik, maka akan memacu mahasiwa untuk belajar dan lebih berkreatifitas sehingga dapat melahirkan generasi yang kreatif dan kompeten dalam profesi keperawatan.

$$
\text { Harapannya pada mahasiswa }
$$
semester IV Prodi Ilmu Keperawatan diberikan pembekalan tentang penggunaan strategi mekanisme koping yang baik untuk mengatasi cemas yang dialami mahasiswa sebelum melaksanakan pembelajaran klinik di rumah sakit agar tidak terjadi perilaku maladaptif.

Tujuan umum dari penelitian ini adalah untuk mengetahui hubungan strategi mekanisme koping dengan tingkat kecemasan menghadapi pembelajaran klinik pada mahasiswa semester IV Prodi Ilmu Keperawatan STIKES Dian Husada Mojokerto. Sedangkan tujuan khusus penelitian ini adalah untuk mengetahui gambaran strategi mekanisme koping, mengetahui gambaran tingkat kecemasan, dan menganalisa hubungan strategi mekanisme koping dengan tingkat kecemasan menghadapi pembelajaran klinik pada mahasiswa semester IV Prodi Ilmu Keperawatan STIKES Dian Husada Mojokerto.

\section{METODE DAN BAHAN}

Jenis penelitian yang digunakan adalah cross-sectional yaitu menganalisis hubungan strategi mekanisme koping dengan tingkat kecemasan menghadapi pembelajaran klinik pada mahasiswa semester IV Prodi Ilmu Keperawatan STIKES Dian Husada Mojokerto dengan cara pendekatan dan observasi atau pengumpulan data sekaligus pada suatu saat.

Populasi dalam penelitian ini yaitu seluruh mahasiswa STIKES Dian Husada Mojokerto semester IV Prodi Ilmu Keperawatan Tahun Pelajaran 2014-2015 sebanyak 67 orang. Kriteria populasi pada penelitian ini yaitu mahasiswa semester IV Prodi Ilmu Keperawatan STIKES Dian Husada Mojokerto Tahun Pelajaran 20142015, bersedia menjadi responden dan berada di tempat saat dilakukan penelitian.

Sampel diambil dengan menggunakan teknik probability sampling dengan jenis cluster sampling (gugus atau kelompok sampling). Pengumpulan data dengan menggunakan kuesioner. Pengambilan sampel pada penelitian ini dilakukan pada mahasiswa semester IV Prodi Ilmu Keperawatan STIKES Dian Husada Mojokerto Tahun Pelajaran 20142015 sesuai dengan jumlah yang sudah dihitung dalam rumus besaran sampel, setelah itu lembar persetujuan menjadi responden akan diberikan kepada mahasiswa. Lalu jika sudah terkumpul mahasiswa yang memenuhi kriteria yang sudah ditentukan maka akan dipilih menjadi responden. Kemudian dari 
responden yang telah terpilih tersebutakan diberi kuesioner untuk pengumpulan data. Kuesioner yang sudah dibagi akan dikumpulkan kembali kepada peneliti jika sudah terisi semua.

\section{HASIL PENELITIAN}

\section{Karakteristik Responden Berdasarkan Jenis Kelamin}

Tabel 1. Karakteristik Responden Berdasarkan Jenis Kelamin Mahasiswa Semester IV Prodi Ilmu Keperawatan STIKES Dian Husada Mojokerto Tahun Pelajaran 2014-2015.

\begin{tabular}{|c|c|c|c|}
\hline No. & $\begin{array}{c}\text { Jenis } \\
\text { Kelamin }\end{array}$ & Frekuensi & $\begin{array}{c}\text { Presentase } \\
(\mathbf{\%})\end{array}$ \\
\hline 1. & Laki-laki & 17 & 29.3 \\
\hline 2. & Perempuan & 41 & 70.7 \\
\hline \multicolumn{2}{|c|}{ Total } & 58 & 100.0 \\
\hline
\end{tabular}

Berdasarkan tabel diatas, karakteristik responden berdasarkan jenis kelamin adalah perempuan sebanyak 70.7 $\%$ (41 responden).

\section{Karakteristik Responden Berdasarkan Usia}

Tabel 2. Karakteristik Responden Berdasarkan Usia Mahasiswa Semester IV Prodi Ilmu Keperawatan STIKES Dian Husada Mojokerto Tahun Pelajaran 20142015.

\begin{tabular}{|c|c|c|c|}
\hline No. & Usia & Frekuensi & $\begin{array}{c}\text { Presentase } \\
(\boldsymbol{\%})\end{array}$ \\
\hline 1. & $17-20$ Tahun & 50 & 86.2 \\
\hline 2. & $21-25$ Tahun & 8 & 13.8 \\
\hline Total & & 58 & 100.0 \\
\hline
\end{tabular}

Berdasarkan tabel diatas, karakteristik usia responden dalam penelitian ini adalah sebagian besar sebanyak 50 reponden (86.2\%) berusia 17 20 tahun.

\section{Karakteristik Responden Berdasarkan Strategi Mekanisme Koping}

Tabel 3. Karakteristik Responden Berdasarkan Strategi Mekanisme Koping Menghadapi Pembelajaran Klinik Mahasiswa Semester IV Prodi Ilmu Keperawatan STIKES Dian Husada Mojokerto Tahun Pelajaran 2014-2015.

\begin{tabular}{|c|c|c|c|}
\hline No & Kategori & Frekuensi & $\begin{array}{c}\text { Presentase } \\
(\mathbf{\%})\end{array}$ \\
\hline 1 & Adaptif & 21 & 36.2 \\
\hline 2 & Maladaptif & 37 & 63.8 \\
\hline \multicolumn{2}{|l|}{ Total } & 58 & 100.0 \\
\hline
\end{tabular}

Berdasarkan tabel diatas, karakteristik strategi mekanisme koping sebagian besar responden $(63.8 \%)$ memiliki strategi mekanisme koping maladaptif yaitu sebanyak 37 responden.

\section{Karakteristik Responden Berdasarkan Kecemasan}

Tabel 4. Karakteristik Responden Berdasarkan Kecemasan Menghadapi Pembelajaran Klinik Mahasiswa Semester IV Prodi Ilmu Keperawatan STIKES Dian Husada Mojokerto Tahun Pelajaran 20142015.

\begin{tabular}{|l|l|c|c|}
\hline No & \multicolumn{1}{|c|}{ Kategori } & Frekuensi & $\begin{array}{c}\text { Presentase } \\
(\boldsymbol{\%})\end{array}$ \\
\hline 1 & Tidak ada kecemasan & 0 & 0 \\
\hline 2 & Kecemasan ringan & 35 & 60.3 \\
\hline 3 & Kecemasan sedang & 14 & 24.1 \\
\hline 4 & Kecemasan berat & 9 & 15.5 \\
\hline 5 & $\begin{array}{l}\text { Kecemasan berat } \\
\text { sekali/ panik }\end{array}$ & 0 & 0 \\
\hline \multicolumn{2}{|l|}{ Total } & 58 & 100.0 \\
\hline
\end{tabular}

Berdasarkan tabel diatas, karakteristik kecemasan sebagian besar responden $(60.3 \%)$ memiliki tingkat kecemasan ringan yaitu sebanyak 35 responden. 
Hubungan Strategi Mekanisme Koping

Dengan Tingkat Kecemasan

Menghadapi Pembelajaran Klinik Pada

Mahasiswa Semester IV Prodi Ilmu

Keperawatan STIKES Dian Husada Mojokerto Tahun Pelajaran 2014-2015.

Tabel 5. Karakteristik Responden Berdasarkan Strategi Mekanisme Koping Dengan Tingkat Kecemasan Menghadapi Pembelajaran Klinik Mahasiswa Semester IV Prodi Ilmu Keperawatan STIKES Dian Husada Mojokerto Tahun Pelajaran 20142015.

\begin{tabular}{|c|c|c|c|c|c|c|c|}
\hline Variabel & \multicolumn{5}{|c|}{ Kecemasan } & Total \\
\hline \multirow{3}{*}{$\begin{array}{c}\text { Strategi } \\
\text { Meka- } \\
\text { nisme } \\
\text { Koping }\end{array}$} & $\begin{array}{c}\text { Kate- } \\
\text { gori }\end{array}$ & $\begin{array}{c}\text { Tidak } \\
\text { ada } \\
\text { cemas }\end{array}$ & $\begin{array}{c}\text { Cemas } \\
\text { ringan }\end{array}$ & $\begin{array}{c}\text { Cemas } \\
\text { sedang }\end{array}$ & $\begin{array}{c}\text { Cemas } \\
\text { berat }\end{array}$ & $\begin{array}{c}\text { Cemas } \\
\text { berat } \\
\text { sekali/ } \\
\text { panik }\end{array}$ & \\
\cline { 2 - 8 } & Adaptif & $0(0 \%)$ & $\begin{array}{c}17 \\
(29.3 \%)\end{array}$ & $3(5.2 \%)$ & $1(1.7 \%)$ & $0(0 \%)$ & $\begin{array}{c}21 \\
(36.2 \\
\%)\end{array}$ \\
\cline { 2 - 8 } & $\begin{array}{c}\text { Mal- } \\
\text { adaptif }\end{array}$ & $0(0 \%)$ & $\begin{array}{c}18 \\
(31.0 \%)\end{array}$ & $\begin{array}{c}11 \\
(19.0 \%)\end{array}$ & $8(13.8 \%)$ & $0(0 \%)$ & $\begin{array}{c}37 \\
63.8 \\
\%)\end{array}$ \\
\hline \multirow{2}{*}{ Total } & $0(0 \%)$ & $\begin{array}{c}35 \\
(60.3 \%)\end{array}$ & $\begin{array}{c}14 \\
(24.1 \%)\end{array}$ & $9(15.5 \%)$ & $0(0 \%)$ & $\begin{array}{c}58 \\
(100.0 \\
\%)\end{array}$ \\
\hline
\end{tabular}

Berdasarkan tabel diatas, karakteristik strategi mekanisme koping dengan tingkat kecemasan sebagian besar responden $(31.0 \%)$ yang menggunakan mekanisme koping maladaptif adalah responden yang memiliki tingkat kecemasan ringan yaitu sebanyak 18 responden.

\section{PEMBAHASAN}

\section{Strategi Mekanisme Koping}

Dari hasil penelitian didapatkan sebagian besar responden $(55.2 \%)$ memiliki strategi mekanisme koping maladaptif yaitu sebanyak 32 responden dari 58 responden. Menurut Stuart dan Sudden dalam Nasir (2011), mekanisme koping berdasarkan penggolongannya dibagi menjadi dua antara lain: Mekanisme koping adaptif yaitu mekanisme koping yang mendukung fungsi integrasi, pertumbuhan, belajar, dan mencapai tujuan.
Dan mekanisme koping maladaptif dimana mekanisme koping yang menghambat fungsi integrasi, memecah pertumbuhan, menurunkan otonomi, dan cenderung menguasai lingkungan.

Strategi mekanisme koping maladaptif yang dimiliki mahasiswa semester IV Prodi Ilmu Keperawatan STIKES Dian Husada Mojokerto dapat menghambat fungsi integrasi mahasiswa dalam menghadapi pembelajaran klinik. Menurut Mu'tadin dalam Indra (2012), adanya strategi mekanisme koping yang maladaptif dipengaruhi oleh beberapa hal, antara lain adalah dukungan social, seperti dukungan pemenuhan kebutuhan informasi dan emosional pada diri mahasiswa dapat mempengaruhi strategi mekanisme koping, karena dengan terpenuhinya kebutuhan informasi seperti tentang cara penggunaan strategi mekanisme koping yang baik, mahasiswa akan menganalisa situasi, mengidentifikasi masalah dengan tujuan untuk menghasilkan alternatif tindakan untuk menyelesaikan masalah. Kemudian mempertimbangkan alternatif tersebut sehubungan dengan hasil yang ingin dicapai.

\section{Tingkat Kecemasan}

Dari hasil penelitian sebagian besar responden $(60.3 \%)$ memiliki tingkat kecemasan ringan yaitu sebanyak 35 responden dari 58 responden. Pada kecemasan terdapat dua faktor penyebab (Stuart \& Laraia, 2005), yaitu faktor internal dan eksternal. Sebagian besar mahasiswa semester IV Prodi Ilmu Keperawatan STIKES Dian Husada Mojokerto memiliki tingkat kecemasan ringan. Namun ada beberapa mahasiswa yang memiliki tingkat kecemasan sedang bahkan berat. Aspek lingkungan sangat 
mempengaruhi cara berpikir tentang diri sendiri atau orang lain, sehingga mahasiswa semester IV Prodi Ilmu Keperawatan STIKES Dian Husada Mojokerto yang pertama kali menghadapi pembelajaran klinik merasakan kecemasan karena perasaan tidak nyaman dan aman terhadap lingkungan baru (Rumah Sakit). Prestasi atau kinerja mahasiswa dapat meningkat karena kecemasan. Namun apabila gejala itu berlebihan akan menjadi menetap atau patologis, kinerja mahasiswa akan menurun dan sulit berkonsentrasi sehingga tidak dapat mengambil keputusan yang tegas. Faktor lingkungan sangat mendukung mahasiswa supaya nyaman untuk dapat mengurangi tingkat kecemasan mahasiswa untuk menghadapi pembelajaran klinik.

\section{Hubungan Strategi Mekanisme Koping} Dengan Tingkat Kecemasan Menghadapi Pembelajaran Klinik Pada Mahasiswa

Dari hasil uji korelasi Spearman Rho variabel strategi mekanisme koping dan variabel kecemasan menunjukkan adanya hubungan antara strategi mekanisme koping dengan tingkat kecemasan menghadapi pembelajaran klinik pada mahasiswa semester IV Prodi Ilmu Keperawatan STIKES Dian Husada Mojokerto. Sedangkan hasil tabulasi silang diperoleh strategi mekanisme koping dengan tingkat kecemasan sebagian besar responden $(31.0 \%)$ yang menggunakan mekanisme koping maladaptif adalah responden yang memiliki tingkat kecemasan ringan yaitu sebanyak 18 responden.

\section{SIMPULAN}

1. Strategi mekanisme koping menghadapi pembelajaran klinik pada mahasiswa semester IV Prodi Ilmu Keperawatan STIKES Dian Husada Mojokerto sebagian besar menggunakan strategi mekanisme koping maladaptif.

2. Tingkat kecemasan menghadapi pembelajaran klinik pada mahasiswa semester IV Prodi Ilmu Keperawatan STIKES Dian Husada Mojokerto dari hasil yang diperoleh sebagian besar memiliki tingkat kecemasan yang ringan.

3. Dari hasil penelitian diketahui ada hubungan strategi mekanisme koping dengan tingkat kecemasan menghadapi pembelajaran klinik pada mahasiswa semester IV Prodi Ilmu Keperawatan STIKES Dian Husada Mojokerto.

\section{SARAN}

Saran dalam penelitian ini adalah untuk para pembimbing mampu mengenali tanda-tanda kecemasan mahasiswa dalam menghadapi pembelajaran klinik dan membantu mahasiswa untuk menemukan strategi mekanisme koping yang baik dalam mengatasi kecemasannya tersebut.

\section{DAFTAR PUSTAKA}

1. AIPNI-AINEC. 2013. Daftar Anggota Asosiasi Institusi Pendidikan Ners Indonesia (AIPNI-AINEC). Diunduh tanggal 15 Desember 2014 pukul 12.30 WIB http://www.aipni-ainec.com.

2. Asmadi. 2008. Teknik Prosedural Keperawatan: Konsep dan Aplikasi Kebutuhan Dasar Klien. Jakarta: Salemba Medika.

3. Az-Zahrani, Musfir. 2005. Konseling Terapi. Jakarta : Gema Insani Press.

4. Carpenito, Lynda Juall. 2009. Diagnosis Keperawatan: Aplikasi pada Praktik Klinis. Jakarta: EGC. 
5. Chrishtensen, Paula J. 2009. Proses Keperawatan: Aplikasi Model Konseptual Edisi 4. Jakarta: EGC.

6. Copel, Linda Carman. 2007. Kesehatan Jiwa dan Psikiatri: Pedoman Klinis Perawat. Jakarta: EGC.

7. Departemen Kesehatan RI. 2013. Riskesdas 2013. Diunduh tanggal 30 Oktober 2014 pukul 14.13 WIB www.litbang.depkes.go.id.

8. Dirckx, John H. 2005. Kamus Ringkas Kedokteran STEDMAN untuk Profesi Kesehatan. Jakarta: EGC.

9. Doenges, Marilynn E. 2006. Rencana Asuhan Keperawatan Psikiatri. Jakarta: EGC.

10. Eisenberg, Daniel et all. 2007. Prevalence and correlates of depression, anxiety, and suicidality among university students. American Journal of Orthopsychiatry. Vol 77. (534-542).

11. Hidayat, A. Aziz Alimul. 2004. Pengantar Konsep Dasar Keperawatan. Jakarta: Salemba Medika.

12. Hidayat, A. Aziz Alimul. 2006. Kebutuhan Dasar Manusia: Aplikasi Konsep dan Proses Keperawatan. Jakarta: Salemba Medika.

13. Hidayat, A. Aziz Alimul. 2008. Riset Keperawatan dan Teknik Penulisan Ilmiah. Jakarta: Salemba Medika.

14. Indra, Sonya Fianna. 2012. Perbedaan Mekanisme Koping Mahasiswa Baru FKM UI Reguler 2011 yang Tinggal Bersama Orang Tua Dengan yang Tidak Tinggal Bersama Orang Tua. Universitas Indonesia. Jakarta, Indonesia.

15. Kaplan \& Sadock. 1997. Sinopsis Psikiatri Ilmu Pengetahuan Prilaku
Psikiatri Klinis. Jakarta: Binarupa Aksara.

16. Keliat, Budi Anna dkk. 2011. Manajemen Kasus Gangguan Jiwa: CMHN (intermediate course). Jakarta: EGC.

17. Kurniawati, Ninuk Dian., Nursalam. 2007. Asuhan Keperawatan Pada Pasien Terinfeksi HIV/AIDS. Jakarta: Salemba Medika.

18. Maharatih, Gst Ayu dkk. 2009. Psikiatri Komprehensif. Jakarta: EGC.

19. Mancevska, S, et al. 2008. Depression, anxiety and substance use in medical students in the Republic of Macedonia. Journal of Bratisl Lek Listy. Vol 12. (109).

20. Mutadin, Zainun. 2002. Pengantar Pendidikan dan Ilmu Perilaku Kesehatan. Yogyakarta: Andi Offset.

21. Nasir, Abdul dkk. 2011. Dasar-Dasar Keperawatan Jiwa: Pengantar dan Teori. Jakarta: Salemba Medika.

22. Nurhidayah, Rika Endah. 2009. Pendidikan Keperawatan. Medan: USU Press.

23. Nursalam. 2008. Pendidikan dalam Keperawatan. Jakarta: Salemba Medika.

24. Nursalam. 2011. Konsep Dan Penerapan Metodelogi Penelitian Ilmu Keperawatan. Jakarta: EGC.

25. Semiun, Yustinus. 2006. Kesehatan Mental 1. Yogyakarta: Kanisius.

26. Stuart \& Laraia. 2005. Principles and Practice of Psychiatric Nursing. St Louis: Mosby Year Book.

27. Stuart, Gail W. 2006. Buku Saku Keperawatan Jiwa. Jakarta: EGC.

28. Suminarsis, Tyas A dkk. 2009. Hubungan Antara Tingkat Kecemasan Dengan Mekanisme Koping Pada Mahasiswa Keperawatan Menghadapi 
Praktek Belajar Lapangan Di Rumah

Sakit. Universitas Surakarta. Surakarta, Indonesia.

29. Syahreni, Elfi dkk. 2007. Pengalaman mahasiswa S1 keperawatan program reguler dalam pembelajaran klinik. Jurnal Keperawatan Indonesia. Volume 11. (47-53).

30. Tamher, S dkk. 2009. Kesehatan Usia Lanjut dengan Pendekatan Asuhan Keperawatan. Jakarta: Salemba Medika.

31. Tomb, David A. 2004. Buku Saku Psikiatri. Jakarta: EGC.

32. Videbeck, Sheila L. 2008. Buku Ajar Keperawatan Jiwa. Jakarta: EGC.

33. Waridah, Ernawati dkk. 2014. Kamus Bahasa Indonesia. Bandung: Ruang Kata.

34. Wasis. 2008. Pedoman Riset Praktis Untuk Profesi Perawat. Jakarta: EGC.

35. Weller, Barbara F. 2005. Kamus Saku Perawat edisi 22. Jakarta: EGC.

36. Wicaksana, Inu. 2008. Mereka Bilang Aku Sakit Jiwa. Yogyakarta: Kanisius.

Cite This Article As: Lestari, Y.A., Suidah, H., Chasanah, N., Nur, E.N. Hubungan Strategi Mekanisme Koping Dengan Tingkat Kecemasan Menghadapi Pembelajaran Klinik Pada Mahasiswa Semester IV Program Studi Ilmu Keperawatan STIKES Dian Husada Mojokerto. Nurse and Health: Jurnal Keperawatan 2018; 7(1): 1-7. 